\title{
Purification treatment on polluted river via combinations of gravel contact oxidation treatment and surface flow constructed wetlands- $A$ case study in Changhua County, Taiwan
}

\section{Chen-Chiang Chou ${ }^{1}$, Wei-Ting Chen ${ }^{2, *}$, Yung-Pin Tsai ${ }^{3, *}$}

1 Doctoral Program, Department of Civil Engineering, National Chi Nan University, Nantou Hsien, 545, Taiwan, ROC; E-mail: ccc6166@yahoo.com.tw

2 Department of Cosmetic Application \& Management, St. Mary's Junior College of Medicine, Nursing and Management, Yilan, 266, Taiwan, ROC; E-mail: chenwt@smc.edu.tw

3 Department of Civil Engineering, National Chi Nan University, Nantou Hsien, 545, Taiwan, ROC; E-mail:yptsai@ncnu.edu.tw

* Correspondence: chenwt@smc.edu.tw; Tel.: +886-3-989-7393 Ext. 651; yptsai@ncnu.edu.tw; Tel.: +886-49-291-0960 Ext. 4959

\begin{abstract}
Polluted river is a primary problem occurred in Changhua County, Taiwan because of rapid and massive developments of agriculture and industry. Water sample belongs to the water exhausted from influent of Yangzi-Cuo river, ci-tong jiao, Changhua County, and ecology technologies, which combined with gravel contact oxidation and surface flow constructed wetlands, are employed to enhance the water quality. Ecology technology is a useful and ordinary process which focuses on original treatment of pollution through chemical, physical, and biological procedures based on the mediums of soil, plant, water, and microorganism from pure environment. Moreover, this study aims on minimizing river pollution index (RPI) of Yangzi-Cuo river by using combinations of gravel contact oxidation and surface flow constructed wetlands. The inflow volume of water sample in suit is measured as 1,534-2,261 cubic meters per day (CMD). The major pollution in water sample involves of suspended solid (SS), ammoniacal nitrogen $\left(\mathrm{NH}_{3}-\mathrm{N}\right)$, total phosphorus (TP), total nitrogen (TN), and biochemical oxygen demand (BOD), and the values of above indexes is ranged as $10.0-26.7 \mathrm{mg} / \mathrm{L}, 0.9-14.0 \mathrm{mg} / \mathrm{L}, 1.2-14.1 \mathrm{mg} / \mathrm{L}$, 11.1-18.2 mg/L, and 0.5-3.6 mg/L, respectively. Efficiencies of pollution elimination on $\mathrm{SS}, \mathrm{NH}_{3}-\mathrm{N}, \mathrm{TP}, \mathrm{TN}$, and BOD were depicted as 24.2-93.1\%, 58.3-86.2\%, 5.2-85.0\%, 59.4$77.2 \%$, and $46.3-76.4 \%$, correspondingly, after purification treatment of ecology
\end{abstract}


technology. As the result, ecology technology is benefit for the purification treatment of polluted river.

Keywords: ecology technology; gravel contact oxidation; surface flow constructed wetlands; water quality; river pollution index 


\section{Introduction}

The household wastewater is a pollution generated from human beings' daily activities. The certain economy of Taiwan is agriculture during past five decades, so excrement from human beings and petted animals are generally used to culture crops. The household wastewater is discharged into river and soil, and the self-purification functions of river and soil are available to degrade these low-grade toxic and much uncomplicated wastes from human beings and petted animals [1-5]. However, the facts of population centralization, enhancement of living quality, development of technology, and variation of living style resulted in enlargement of discharged wastewater with much complicated water contents. The self-purification functions of river and soil were not available to afford these large amounts wastewater with much complicated water contents. As the result, the problem of river and soil pollution turned to much serious continuously. Both of industrial business and agricultural activities are the main economy of Changhua County, and the population of Changhua County reaches to 1.3 million, which produced plenty of wastewater consequently. Based on the estimated historical data from Environment Protection Administration (EPA), the certain river pollution is industrial wastewater during past five decades in Taiwan. After the implement of environment protection regulations, the problem of industrial wastewater has been resolved.

However, there is approximately $47 \%$ of wastewater production belonged to the household wastewater, and the household wastewater is ranged as the most serious issue among wastewater productions from varied business in Taiwan. Moreover, the popularizing rate of public sewage treatment is only $6.3 \%$ at 2008 in Changhua County, and most household wastewater is usually discharged directly into river through drain with rain. As the result, the discharged household wastewater dramatically polluted the quality of river. There were many purification technologies, including membrane filtration, wet pyrolysis, coagulation process, and anaerobic digestion [6-9], used on waste and wastewater treatment. Besides, the EPA started to announce many policies and strategies regarding wastewater pollution treatment to local government since 2002. For example, the announced method included gravel contact oxidation treatment, surface flow constructed wetland, and aeration facility for wastewater purification [10-18]. The principle of these wastewater purification focused on interaction of wastewater and natural environmental 
factors, such as oxygen, soil, microorganism, and plants, to purify water quality for eliminating the pollution capacity of river via decrease of discharged wastewater.

The onsite wastewater treatment system (OWTS) is a novel ecological engineering to purify river quality in Taiwan. The efficiency of OWTS aims on wastewater treatment and water quality purification via natural mechanism and energy, and the mechanism is described as by using fundamentally physical, chemical, and biological methods with consideration of onsite environmental conditions, including pollution category, soil quality, gradient value, flow rate, and gravel type to achieve the maximum efficiency of wastewater treatment. Metcalfand Eddy [19] declared that there were two natural wastewater treatment systems, including soil/land treatment system and aquatic-based treatment system, and these two systems consisted of some clear methods individually. The soil/land treatment system contained slow rate, rapid infiltration, and overland flow methods, and the aquaticbased treatment system involved of surface flow constructed wetland, natural wetland, and aquatic plant methods. However, gravel contact oxidation treatment is the common useful method in Taiwan, and this method is initially developed by Japan government for river quality purification [20].

The EPA collected data of domestic river quality in 25 positions by conducing project of river quality purification technology design at 2005-2006 and summarized the results of domestic river quality in 25 positions after implementing purification technology. Moreover, the variation of biochemical oxygen demand (BOD), ammonia nitrogen $\left(\mathrm{NH}_{3}-\right.$ $\mathrm{N}$ ), total phosphorus (TP), and suspended solid (SS) are available to present the removal efficiency of wastewater pollution via gravel contact oxidation treatment, which can be applied as a reference on operation of river quality natural purification treatment. As the result, this study employed gravel contact oxidation treatment to purify the water quality of Yangzi-Cuo river in ci-tong jiao, Changhua County. 


\section{Experimental and methodology}

\subsection{Introduction of gravel contact oxidation treatment}

Gravel contact oxidation treatment is a fast method among natural purification technologies, and its rule is defined that the organism of wastewater is available to be decomposed by bio-membrane attached on gravel after wastewater flow rapidly through gravel [21]. Gravel is the main component used in gravel contact oxidation treatment, and material with particle diameter of 0.6-1.2 $\mathrm{mm}$, as subordinate substance, is also available to apply in gravel contact oxidation treatment. For instance, coal cinder and coke are also suitable for application of gravel contact oxidation treatment. There are usually two layers structure of gravel arrangement in gravel contact oxidation treatment to enhance the efficiency of wastewater decomposition, and the interval of upper and lower gravel layers are loose and tight, respectively. Furthermore, flow rate is high to maintain aerobic statue in the condition of upper gravel layer, and flow rate is low to form anaerobic statue in the circumstance of lower gravel layer. The two gravel layers condition is defined as double contact system, and the hydraulic loading rate (HLR) is approximately averaged as 0.47 $\mathrm{m} /$ day. Particle diameter is the priority factor in wastewater pollution treatment, and flow rate is rather slow if the particle size is much small to result in great removal efficiency of high concentration of wastewater pollution. Moreover, Seidel [22] investigated that gravel with particle size less $0.06 \mathrm{~m}$ is suitable for aquatic plant growth because this environment provides large surface area of aquatic plant's root to let much microorganism attach on, resulted in maintaining aquatic plant's growth.

Based on the Darcy's law [23-27], relationship for flow rate of water in sand filters were determined through a report on the construction of the Dijon, France, municipal water system. The volume flow rate $(q)$ represented as gradient of elevation $(\mathrm{z})$ at horizontal direction of water flow (x), and equation 1 was used to describe the relationship of $\mathrm{Q}, \mathrm{z}$ and $\mathrm{x}$.

$$
q=-K_{s} \frac{d z}{d x}
$$

where $\mathrm{q}$ is volume flow rate; Ks symbolizes as saturated hydraulic conductivity; $\mathrm{z}$ represents as gradient of elevation; and $\mathrm{x}$ depicts as horizontal direction of water flow. 
Moreover, equation 2 discussed the connection of $\mathrm{q}$ and volume flow rate of underwater (Q).

$Q=q A$

where $\mathrm{Q}$ stands for volume flow rate of underwater, and A describes the area of gravel wetland. In a more detailed way, multiplication of gradient of elevation and width of wetland (1) gains outcome of $\mathrm{A}$, as depicted in equation 3 .

where 1 is width of wetland.

$A=l z$

Equation 4 can be obtained after the substitution of equations 2 and 3 into equation 1, as shown in the following equation.

$Q=-K_{s} l z \frac{d z}{d x}$

After integration on both side of equal sign, equation 5 can be acquired, as illustrated as follows.

$$
Q \int_{0}^{x} d x=-K_{s} l \int_{z_{0}}^{z} z d z
$$

where $z_{0}$ represents as initial elevation of inflow, and $z$ stands for current elevation of inflow at any time. Summary of equation 5 can present outcome of equation 6 , as shown in the following equation.

$$
\frac{2 Q x}{K_{s} l}=z_{0}^{2}-z^{2}
$$

Furthermore, equation 5 also can depict different functional equation, as shown in equation 7.

$$
z=\sqrt{z_{0}^{2}-\frac{2 Q}{K_{s} l} x}
$$

Equation 8 mentions the hydraulic retention time (HRT) of flow in wetland, as depicted as follows.

$$
H R T=\frac{V}{Q}
$$

where HRT represents as hydraulic retention time, and V is the volume on water inside of wetland. Moreover, V is calculated by multiplication of porosity $(\phi)$, width of wetland (l), elevation (z), and horizontal direction of water flow (x), as depicted in equation 9. 
$V=\phi \operatorname{lz} x$

where $\phi$ represents porosity.

Equation 10 can be derived from calculation of equation 8, as shown as follows.

$d H R T=\frac{d V}{d Q}$

After the substitution of equation 9 to equation 10, a new combination can be acquired, as illustrated in equation 11.

$d H R T=\frac{\phi l}{Q} z d x$

Besides, the substitution of equation 7 to equation 11 can derive equation 12, as presented in the following equation.

$\int_{0}^{H R T} d H R T=\frac{\phi l}{Q} \int_{0}^{x}\left(z_{0}^{2}-\frac{2 Q}{K_{s} l} x\right)^{1 / 2} d x$

Equation 13 can be obtained by summary of equation 12, as shown as follows.

$$
H R T=\frac{\phi K_{s} l^{2}}{3 Q^{2}} z_{0}^{3}\left[1-\left(1-\frac{2 Q}{K_{s} l z_{0}^{2}} x\right)^{3 / 2}\right]
$$

In the assumption situation, first-order reaction can match the condition of purification on quality of wastewater in the wetland, and the above condition can be described in equation 14 , as depicted in the following equation.

$C=C_{0} e^{-k H R T}$

where $\mathrm{C}_{0}$ represents the concentration of inflow; $\mathrm{C}$ is the concentration of outflow; and $\mathrm{k}$ depicts the coefficient of first-order reaction.

According to the perspective of equations 13 and 14, decomposition reaction of pollution in wastewater can be presented, and the two factors of $\mathrm{k}$ and HRT are much important among those hydraulic parameters. Furthermore, value of HRT is varied by many factors, such as saturated hydraulic conductivity $(\mathrm{Ks})$, porosity $(\phi)$, volume of flow, and elevation (z). As the results, the factors of hydraulic conductivity (Ks) and porosity $(\phi)$ are useful on the construction, and the operational situation of wetland are determined by the parameters of volume of flow and elevation (z). Decomposition reaction of pollution is altered by the growth condition of biomembrane.

\subsection{The proper design processes of a constructed wetland}


There are six core processes to design a constructed wetland, and those processes are listed as follows.

(1) Estimation on amount of rain fall via collection of atmospheric data in a specific area.

(2) Evaluation on amount of vaporization by evaporation pan method and on-site evaporating test.

(3) Calculation of soil infiltration data.

(4) Calculation on HRT, volume of flow, and design area of constructed wetland by applying first-order model $-\mathrm{k}-\mathrm{C}^{*}$ model (common used in the surface flow wetland) or Monod Kinetics model (general applied in the subsurface flow wetland) with consideration of environmental temperature and species of pollution [28].

(5) Computation on averaged volume of flow via hydrographic data for adjusting volume of flow and design area.

(6) Collection on geographical data of constructed wetland. 


\section{Results and discussions}

\subsection{Removal efficiency of SS}

Initial SS concentration of inflow is ranged in $12.0-62.0 \mathrm{mg} / \mathrm{L}$, and removal efficiency of wastewater via gravel contact oxidation results in $3-75 \%$, as shown in Figure 1. Moreover, removal efficiency of wastewater tends to high value if the inflow concentration is high. As the results, SS can be removed obviously by using gravel contact oxidation treatment. Furthermore, removal efficiency varied dramatically if the inflow concentration is lower than $20 \mathrm{mg} / \mathrm{L}$ to result in obscured outcome on wastewater treatment. The SS concentration of outflow is less $20 \mathrm{mg} / \mathrm{L}$ after gravel contact oxidation treatment to induce removal efficiency of surface flow constructed wetland also varied dramatically. Figure 2 shows that SS concentration of outflow is $15.2 \mathrm{mg} / \mathrm{L}$ at October, and decomposition of fallen leaves from aquatic plant, deposits release from bottom, and biomembrane dropped fall in constructed wetland flow out with water to result in this phenomenon as SS background concentration. Moreover, treatment loading will be increased and SS concentration will be enhanced because of this phenomenon, and the removal efficiency of entire system is ranged as 46-96\%, as depicted in Figure 3. Furthermore, sedimentation basin can be used to collect sands with above particle diameter of $2 \mathrm{~mm}$ to prevent those sands flow to gravel contact oxidation tank without sands primary filter, resulted in reduction on usable capacity of gravel contact oxidation tank because of sands accumulation.

\subsection{Removal efficiency of $B O D$}

Removal efficiency of BOD located in the range of $-14-54 \%$ by gravel contact oxidation treatment, as shown in Figures 4 and 5. Figure 5 shows that BOD concentration in May increases from 3.9 to $5.6 \mathrm{mg} / \mathrm{L}$, and removal efficiency of BOD is similar via gravel contact oxidation treatment and constructed wetland method. The BOD of final outflow located in concentration of $1.6-6.5 \mathrm{mg} / \mathrm{L}$, and these results were stable and matched with the request of BOD standard. Furthermore, the proper BOD concentration is less than 10 $\mathrm{mg} / \mathrm{L}$. Figure 6 depicts BOD concentrations of outflow in the entire system are lower than 
maximum concentration limit of outflow, where the maximum concentration limit is 17 $\mathrm{mg} / \mathrm{L}$, after gravel contact oxygen treatment and constructed wetland method.

\subsection{Removal efficiency of TN}

Figure 7 illustrates removal efficiency of TN is between $17-74 \%$ via gravel contact oxidation treatment, and Figure 8 depicts removal efficiency of TN locates in 2-67\% by constructed wetland method. Removal efficiency of $\mathrm{TN}$ in the entire system (combination of gravel contact oxidation treatment and constructed wetland method) resulted in 57-88 $\%$. Although these removal efficiencies of TN in both of June and November are not excess $60 \%$ by using gravel contact oxidation treatment and constructed wetland method, TN concentration of outflows in June and November are 3.3 and $3.5 \mathrm{mg} / \mathrm{L}$, respectively, where both of those values are stable and less than $5 \mathrm{mg} / \mathrm{L}$. Figure 9 illustrates TN concentration variation of inflow and outflow in the entire system, where the maximum concentration limit of outflow is $7 \mathrm{mg} / \mathrm{L}$, and most TN concentrations are lower than the maximum concentration limit, excepted the values in April and June. Although approximately 63\% of TN in April can be eliminated, the TN concentration in April is the maximum value, resulted in the TN concentration of outflow can not be lower than the maximum concentration limit due to higher loading of pollution treatment. Furthermore, there is roughly $63 \%$ of TN in June, and the TN concentration in June is the secondly large value. As the result, the loading of pollution treatment is close to $60 \%$, and $\mathrm{TN}$ removal efficiency of the entire system can reach to closely $60 \%$.

\subsection{Removal efficiency of TP}

Phosphate is one nutrient of growth factor for microorganisms and algae, and the demand dose of phosphate as nutrient source is only rated as 1/100 of carbohydrate source. Moreover, Figures 10 and 11 show that TP concentration of inflow is $2.6 \mathrm{mg} / \mathrm{L}$, and TP concentration of outflow locates in concentration of $1.4 \mathrm{mg} / \mathrm{L}$, as ranged as the maximum value in all inflow and outflow values correspondingly. Removal efficiency of TP in entire system ranged in $12-82 \%$, as shown in Figure 12, and the following steps could achieve the high value of removal efficiency. For example, digestion and adsorption occurred 
actively in growth for microorganisms and algae, and removal efficiency of TP was also altered by the traits of sands sample. According to researches of Akratos and Tsihrintzis [29], natural sands consisted of the components of $\mathrm{Fe}, \mathrm{Al}$ and $\mathrm{Ca}$, where the components of natural sands were different with plastic filter samples, and ions of phosphate carried electric charge to be adsorbed by positive charge ions, $\mathrm{Fe}, \mathrm{Al}$ and $\mathrm{Ca}$. Furthermore, the regular disposal of spoil helped pollution elimination.

However, the effect of reverse flushing via gravel was not obvious accompanying with operational time of gravel contact oxidation treatment and constructed wetland method, which resulted in sludge deposit to decrease removal efficiency, as assumption for reduction on removal efficiency of TP. Otherwise, the adsorption of bottom soil and digestion of aquatic plant for growth in constructed wetland also enhanced the removal efficiency of TP.

\subsection{Removal efficiency of $\mathrm{NH}_{3}-\mathrm{N}$}

Figure 13 shows that the maximum $\mathrm{NH}_{3}-\mathrm{N}$ concentration of inflow is $13.9 \mathrm{mg} / \mathrm{L}$ by using gravel contact oxidation treatment, and the removal efficiency of $\mathrm{NH}_{3}-\mathrm{N}$ reaches to the maximum value of $98 \%$. Most $\mathrm{NH}_{3}-\mathrm{N}$ concentrations during the whole year are lower despite higher $\mathrm{NH}_{3}-\mathrm{N}$ concentrations in April and July, as shown in Figure 14. Figure 14 depicts that the removal efficiency of $\mathrm{NH}_{3}-\mathrm{N}$ reaches to the maximum value of $92 \%$ by using constructed wetland method. Although the $\mathrm{NH}_{3}-\mathrm{N}$ concentration in May is lower than $0.04 \mathrm{mg} / \mathrm{L}$ and the $\mathrm{NH}_{3}-\mathrm{N}$ concentration in August is not detected (ND), the entire removal efficiency reaches to $100 \%$, as illustrated in Figure 15.

\subsection{Summary of pollutions control and analysis on river pollution index of inflow and outflow}

Summary of varied positions by gravel contact oxidation treatment and constructed wetland method depicted that removal efficiencies of SS, BOD, TN, TP, and $\mathrm{NH}_{3}-\mathrm{N}$ removal efficiencies all could reach maximum values, if the inflow concentration is much higher value. However, some inflow concentration is lower to result in removal efficiency unstable and treatment efficiency unclear. Therefore, better removal efficiency occurred in 
the situation of high concentration pollution loading. River pollution index (RPI) is a comprehensive index for evaluation of river quality, which is currently used in EPA to estimate degree of river pollution, and there are four parameters consisted in RPI, including oxygen demand, (DO), biochemical oxygen demand (BOD), suspended solid (SS), and ammonia nitrogen $\left(\mathrm{NH}_{3}-\mathrm{N}\right)$. The evaluation method is listed in table 2, and the value of $\mathrm{RPI}$ is $(\Sigma \mathrm{Ni}) / 4$, where Ni depicts as the point on degree of different pollutions. Moreover, RPI value is summary of point on degree of different pollutions, as ranged in 1-10, and four degrees of water pollution are involved to differentiate degree of pollution. This study adopted the wastewater from outflow of Yangzi-Cuo river, ci-tong jiao, as the test sample, and the water returned to original river after gravel contact oxidation treatment and constructed wetland method. Moreover, RPI index was used to evaluate the purification performance of wastewater. Based on the data collection regarding inflow and outflow of DO, BOD, SS, and $\mathrm{NH}_{3}-\mathrm{N}$ from 101/04-101/12, results of RPI indexes were presented in Table 2 , and the water quality did improve validly after wastewater treatments. The original wastewater belonged to serious pollution, and the final water quality turned to slight pollution and median pollution, as shown in Figure 16. Furthermore, the water quality in July could not reach to the level of slight pollution and little pollution, because many insecticides were applied to eliminate snails in farms to result in residual insecticides flowed to Yangzi-Cuo river, ci-tong jiao to pollute the water quality. Figure 17 shows wastewater variation of upstream and downstream outflow, and the water quality of downstream outflow depicts better outcome after wastewater treatment. Furthermore, the original inflow with RPI index of serious pollution varied to outflow with RPI indexes of slight pollution and median pollution. 


\section{Conclusions}

A case study focused on river quality enhancement in Changhua via cooperation with Environmental Protection Bureau of Changhua County. This study presented the result of degradation on river pollution at Yangzi-Cuo river, ci-tong jiao, Changhua County, Taiwan by employing treatments of gravel contact oxidation and surface flow constructed wetlands. Gravel contact oxidation and surface flow constructed wetlands belonged to ecology technology, where ecology technology aimed on using physical, chemical, and biological designs to eliminate river pollution via the mediums of soil, plant, water, and microorganism from original environment. Moreover, RPI reduction was applied to evaluate the efficiency of river quality enhancement. Initial values of $\mathrm{SS}, \mathrm{NH}_{3}-\mathrm{N}, \mathrm{TP}, \mathrm{TN}$, and BOD were averaged as 10.0-26.7 mg/L, 0.9-14.0 mg/L, 1.2-14.1 mg/L, 11.1-18.2 mg/L, and $0.5-3.6 \mathrm{mg} / \mathrm{L}$ correspondingly, and final values of $\mathrm{SS}, \mathrm{NH}_{3}-\mathrm{N}, \mathrm{TP}, \mathrm{TN}$, and BOD turned to $1.4-8.0 \mathrm{mg} / \mathrm{L}, 0.3-2.13 \mathrm{mg} / \mathrm{L}, 0.22-2.4 \mathrm{mg} / \mathrm{L}, 3.35-5.53 \mathrm{mg} / \mathrm{L}$, and $0.5-7.4 \mathrm{mg} / \mathrm{L}$ after purification treatment by ecology technology. Therefore, efficiencies of pollution elimination on $\mathrm{SS}, \mathrm{NH}_{3}-\mathrm{N}, \mathrm{TP}, \mathrm{TN}$, and BOD were depicted as 24.2-93.1\%, 58.3-86.2\%, $5.2-85.0 \%, 59.4-77.2 \%$, and 46.3-76.4\%, respectively. This study depicted great outcome of river pollution reduction by using combinations of gravel contact oxidation and surface flow constructed wetlands on a case in Changhua County, Taiwan.

Conflicts of Interest: The authors declare no conflicts of interest. 


\section{Reference}

1. Ichinari, T.; Ohtsubo, A.; Ozawa, T.; Hasegawa, K.; Teduka, K.; Oguchi, T.; Kiso, Y. Wastewater treatment performance and sludge reduction properties of a household wastewater treatment system combined with an aerobic sludge digestion unit. Process Biochem. 2008, 43, 722-728.

2. Li, Z.; Li, M.; Liu, X.; Ma, Y.; Wu, M. Identification of priority compounds in groundwater recharge of. China. Sci. Total Environ. 2014, 493, 481-486.

3. Daude, D.; Stephenson, T. Cost-effective treatment solutions for rural areas: design and operation of a new package treatment plant for single households. Water Sci. Technol. 2004, 48, 107-114.

4. Metcalf, Eddy, Wastewater Engineering: Treatment, Disposal, and Reuse, 4th ed. McGraw-Hill, New York, 2003.

5. Nakajima, J.; Fujimura, Y.; Inamori, Y. Performance evaluation of on-site treatmentfacilities for wastewater from households, hotels and restaurants. Water Sci. Technol. 1999, 39, 85-92.

6. Akhondi E.; Zamani F.; Tng K.H.; Leslie G.; Krantz B.W.; Fane G.A.; Chew J.W. The performance and fouling control of submerged hollow fiber (HF) systems: A review. Appl. Sci. 2017, 7, 765-803.

7. Chung J.W.; Edewi O.C.; Foppen J.W.; Gerner G.; Krebs R.; Luc Lens P.N. Removal of Escherichia coli by intermittent operation of saturated sand columns supplemented with hydrochar derived from sewage sludge. Appl. Sci. 2017, 7, 839-852.

8. Abrha Y.W.; Kye H.; Kwon M.; Lee D.; Kim K.; Jung Y.; Ahn Y.; Kang J.W. Removal of algae, and taste and odor compounds by a combination of plant-mineral composite (PMC) coagulant with UV-AOPs: Laboratory and pilot scale studies. Appl. Sci. 2018, 8, 1502-1516.

9. Morales-Polo C.; Cledera-Castro M.d.M.; B. Soria Y.M. Reviewing the anaerobic digestion of food waste: From waste generation and anaerobic process to its perspectives. Appl. Sci. 2018, 8, 1084-1118.

10. Wu S.; Austin D.; Liu L.; Dong R. Performance of integrated household constructed wetland for domestic wastewater treatment in rural areas. Ecol. Eng. 2011, 37 948954.

11. Chen G.Q.; Shao L.; Chen Z.M.; Li Z.; Zhang B.; Chen H.; Wu Z.; Low-carbon assessment for ecological wastewater treatment by a constructed wetland in Beijing. Ecol. Eng. 2011, 37 622-628.

12. Ma T.; Zhanga L.; Xia B.; Xiong Y.; Yu P.; Lia G.; Lia J.; Zhao C. Treatment of farmer household tourism wastewater using iron-carbon micro-electrolysis and horizontal subsurface flow constructed wetlands: A full-scale study. Ecol. Eng. 2018, 110 192-203.

13. Álvarez, J.A.; Ruíz, I.; Soto, M. Anaerobic digesters as a pretreatment for constructed wetlands. Ecol. Eng. 2008, 33 (1), 54-67.

14. Abou-Elela S.I.; Golinielli G.; Abou-Taleb E.M.; Hellal M.S. Municipal wastewater treatment in horizontal and vertical flows constructed wetlands Ecological Engineering 61. Ecol. Eng. 2013, 61, 460-468 (Part A). 
15. Alvarez-Zaldívar P.; Centler F.; Maier U.; Thullner M.; Imfeld G. Biogeochemical modelling of in situ biodegradation and stable isotope fractionation of intermediate chloroethenes in a horizontal subsurface flow wetland. Ecol. Eng. 2016, 90, 170-179.

16. Andreo-Martínez P.; García-Martínez N.; Quesada-Medina J.; Almela L. Domestic wastewaters reuse reclaimed by an improved horizontal subsurface-flow constructed wetland: a case study in the southeast of Spain. Bioresour. Technol. 2017, 233, 236246.

17. Bruun J.; Pugliese L.; Hoffmann C.C.; Kjaergaard C. Solute transport and nitrate removal in full-scale subsurface flow constructed wetlands of various designs treating agricultural drainage water. Ecol. Eng. 2016, 97, 88-97.

18. Butterworth E.; Dotro G.; Jones M.; Richards A.; Onunkwo P.; Narroway Y.; Jefferson B. Effect of artificial aeration on tertiary nitrification in a full-scale subsurface horizontal flow constructed wetland. Ecol. Eng. 2013, 54, 236-244.

19. Metcalf and Eddy, Inc., Wastewater Engineering: Treatment, Disposal, and Reuse. 3rd Edition, McGraw-Hill, Inc., Singapore, 1991.

20. Fan Z.H.; Wang W.H. A review on organic pollution removal efficiency by gravel contact oxidation treatment. Academic paper of Environmental Protection Society of Taiwan, 2006, 29(2), 91-102.

21. Kinnicutt L.P. The prevention of the pollution of streams by modern methods of sewage treatment. Science 1902, 16, 161-171.

22. Seidel K. Pflanzungen zwischen Gewässern und Land. Mitteilungen Max-Planck Gesselschaft. 1953, pp. 17-20.

23. Seidel K. Die Flechtbinse Scirpus lacustris. In: Ökologie, Morphologie und Entwicklung, ihre Stell Bedeutung. Schweizerbart'sche Verlagsbuchnadlung, Stuttgart, Germany. 1955, pp. 37-52.

24. Darcy H. Rapport a' le Maire et au Conseil Municipal, de Dijon, sur les Moyens de Fournir l'Eau Ne'cessaire a` cette Ville, Douillier, Dijon, France. 1834.

25. Darcy H. Rapport a' M. le Ministre des Travaux Publics, sur le pavage et le macadamisage des chausse'es de Londres et de Paris, Ann. Ponts Chausse'es. Ser. $1850,2,10,1-264$.

26. Darcy H. Les Fontaines Publiques de la Ville de Dijon, Dalmont, Paris. 1856.

27. Darcy H. Recherches Experimentales Relatives au Mouvement de l'Eau dans les Tuyaux, Mallet-Bachelier, Paris. 1857.

28. Darcy H. Relative a` quelques modifications a` introduire dans le tube de Pitot, Ann. Ponts Chausse'es, Ser. 1858, 3, 15, 351-359.

29. Kadlec R.H.; Knight R.L. Treatment Wetlands. Lewis Publishers, U.S.A, 1996. 


\section{Table captions}

Table 1. Specifications on design of a constructed wetland.

Table 2. Calculation of RPI and degree of pollution on different items. 
Table 1. Specifications on design of a constructed wetland.

\begin{tabular}{|c|c|}
\hline Items & Conditions \\
\hline Designed method & Gravel contact oxidation and surface flow constructed wetland \\
\hline \multirow[t]{2}{*}{ Area } & a. Total base area: 9,000 square meter. \\
\hline & b. Water purification treatment area: 730 square meter. \\
\hline Inflow source & Household wastewater in ci-tong jiao, Changhua County. \\
\hline \multirow[t]{2}{*}{ Treatment location } & Land numbers of $1-4$ and $1-5$ in ci-tong jiao, Changhua County. \\
\hline & Coordinates position: $(23.070949,120.505699)$. \\
\hline Inflow way & Gravity type and pumping motor diversions \\
\hline Treatment capacity & 2000 cubic meters per day (CMD) \\
\hline Inflow concentration & BOD5: $50 \mathrm{mg} / \mathrm{L} ; \mathrm{NH}_{3}-\mathrm{N}: 80 \mathrm{mg} / \mathrm{L} ; \mathrm{SS}: 50 \mathrm{mg} / \mathrm{L}$ \\
\hline Outflow concentration & BOD5: $20 \mathrm{mg} / \mathrm{L} ; \mathrm{NH}_{3}-\mathrm{N}: 48 \mathrm{mg} / \mathrm{L} ; \mathrm{SS}: 20 \mathrm{mg} / \mathrm{L}$ \\
\hline Removal capacity & BOD5: $20 \mathrm{Kg} / \mathrm{D} ; \mathrm{NH}_{3}-\mathrm{N}<5 \mathrm{Kg} / \mathrm{D} ; \mathrm{SS}<20 \mathrm{Kg} / \mathrm{D} ; \mathrm{TP}<5 \mathrm{Kg} / \mathrm{D}$ \\
\hline Removal efficiency & BOD5: $60 \%$; $\mathrm{NH}_{3}-\mathrm{N}: 40 \%$; SS: $60 \%$; TP: $60 \%$ \\
\hline HRT & 2.59 days \\
\hline $\begin{array}{l}\text { Expectation of purified } \\
\text { outflow concentration }\end{array}$ & BOD5: $20 \mathrm{mg} / \mathrm{L} ; \mathrm{NH}_{3}-\mathrm{N}: 5 \mathrm{mg} / \mathrm{L} ; \mathrm{SS}: 20 \mathrm{mg} / \mathrm{L} ; \mathrm{TP}: 5 \mathrm{mg} / \mathrm{L}$ \\
\hline
\end{tabular}

Table 2. Calculation of RPI and degree of pollution on different items.

\begin{tabular}{|c|c|c|c|c|}
\hline item $\backslash$ degree of pollution & little pollution & slight pollution & median pollution & serious pollution \\
\hline Oxygen demand (mg/L) & $>6.5$ & $3.6-6.5$ & $2.0-3.5$ & $<2.0$ \\
\hline $\begin{array}{l}\text { Biochemical oxygen } \\
\text { demand }(\mathrm{mg} / \mathrm{L})\end{array}$ & $<3.0$ & $3.0-3.9$ & $5.0-15$ & $>15$ \\
\hline Suspended solid (mg/L) & $<20$ & $20-49$ & $50-100$ & $>100$ \\
\hline Ammonia nitrogen $(\mathrm{mg} / \mathrm{L})$ & $<0.5$ & $0.5-0.99$ & $1.0-3.0$ & $>3.0$ \\
\hline $\begin{array}{l}\text { Point on degree of } \\
\text { different pollutions }\end{array}$ & 1 & 3 & 6 & 10 \\
\hline RPI value & $<2.0$ & $2.0-3.0$ & $3.1-6.0$ & $>6.0$ \\
\hline
\end{tabular}




\section{Figure captions}

Figure 1. SS concentration variation of inflow and outflow by using gravel contact oxygen treatment.

Figure 2. SS concentration variation of inflow and outflow via constructed wetland method.

Figure 3. SS concentration variation of inflow and outflow in the entire system by gravel contact oxygen treatment and constructed wetland method.

Figure 4. BOD concentration variation of inflow and outflow by using gravel contact oxygen treatment.

Figure 5. BOD concentration variation of inflow and outflow via constructed wetland method.

Figure 6. BOD concentration variation of inflow and outflow in the entire system by gravel contact oxygen treatment and constructed wetland method.

Figure 7. TN concentration variation of inflow and outflow by using gravel contact oxygen treatment.

Figure 8. TN concentration variation of inflow and outflow via constructed wetland method.

Figure 9. TN concentration variation of inflow and outflow in the entire system by gravel contact oxygen treatment and constructed wetland method.

Figure 10 TP concentration variation of inflow and outflow by using gravel contact oxygen treatment. 
Figure 11. TP concentration variation of inflow and outflow via constructed wetland method.

Figure 12. TP concentration variation of inflow and outflow in the entire system by gravel contact oxygen treatment and constructed wetland method.

Figure 13. $\mathrm{NH}_{3}-\mathrm{N}$ concentration variation of inflow and outflow by using gravel contact oxygen treatment.

Figure 14. $\mathrm{NH}_{3}-\mathrm{N}$ concentration variation of inflow and outflow via constructed wetland method.

Figure 15. $\mathrm{NH}_{3}-\mathrm{N}$ concentration variation of inflow and outflow in the entire system by gravel contact oxygen treatment and constructed wetland method.

Figure 16. RPI values of inflow and outflow.

Figure 17. RPI values of upstream and downstream outflow. 


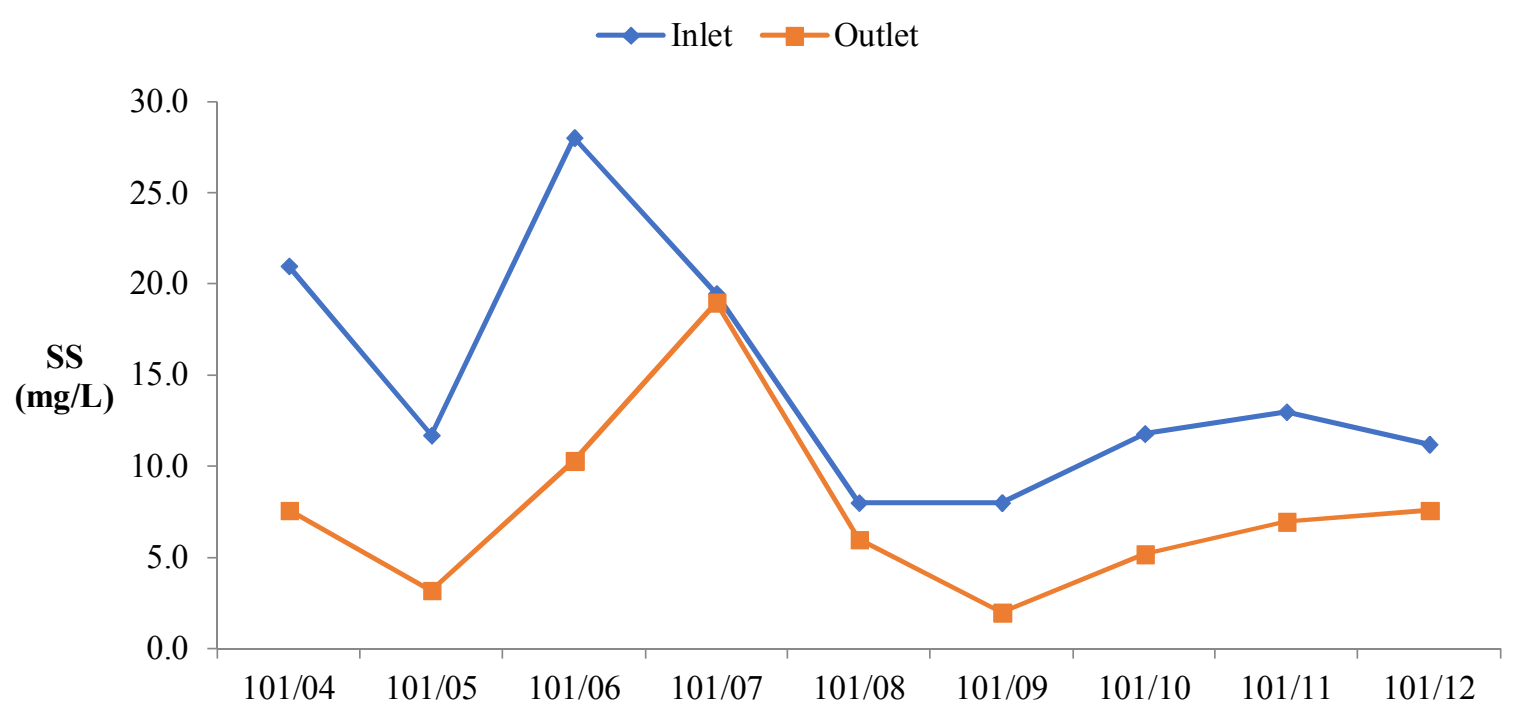

Figure 1. SS concentration variation of inflow and outflow by using gravel contact oxygen treatment.

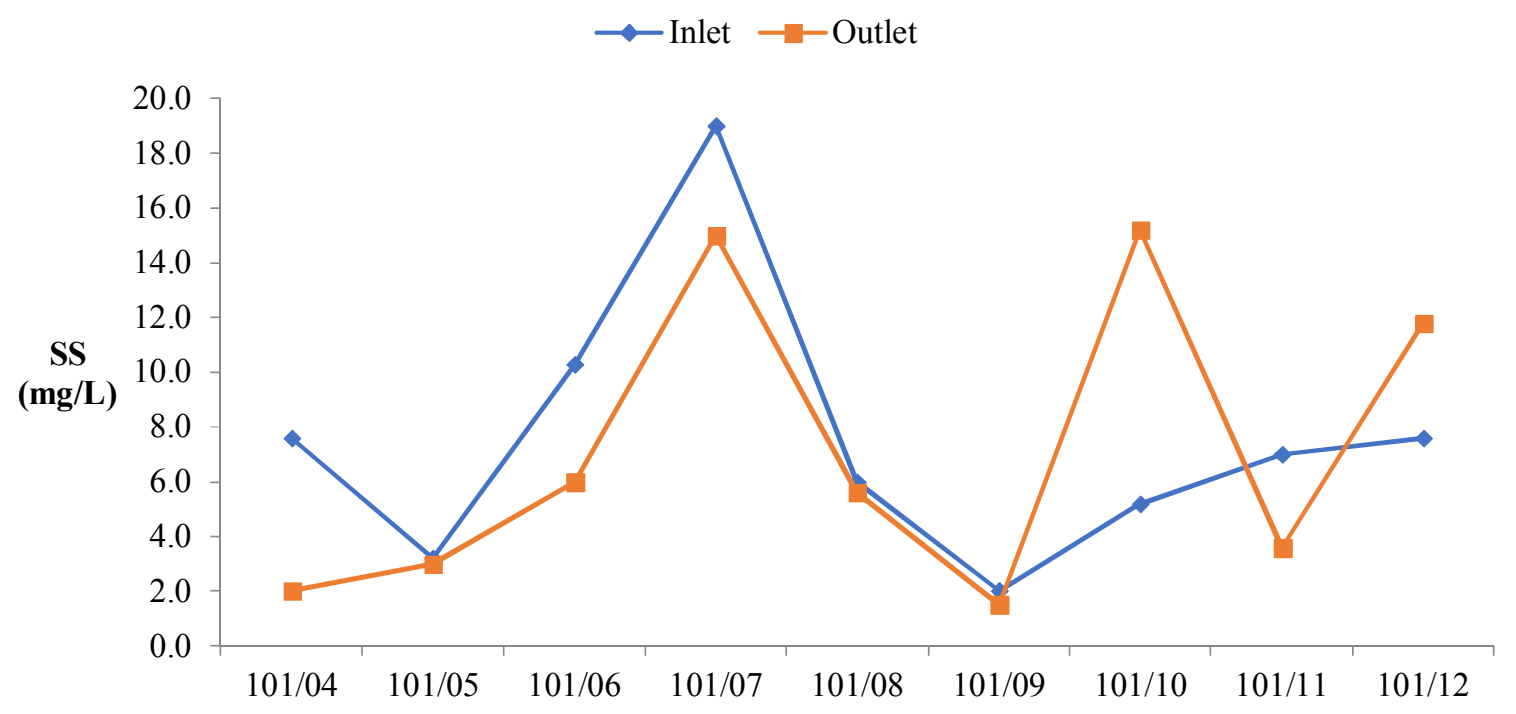

Figure 2. SS concentration variation of inflow and outflow via constructed wetland method. 


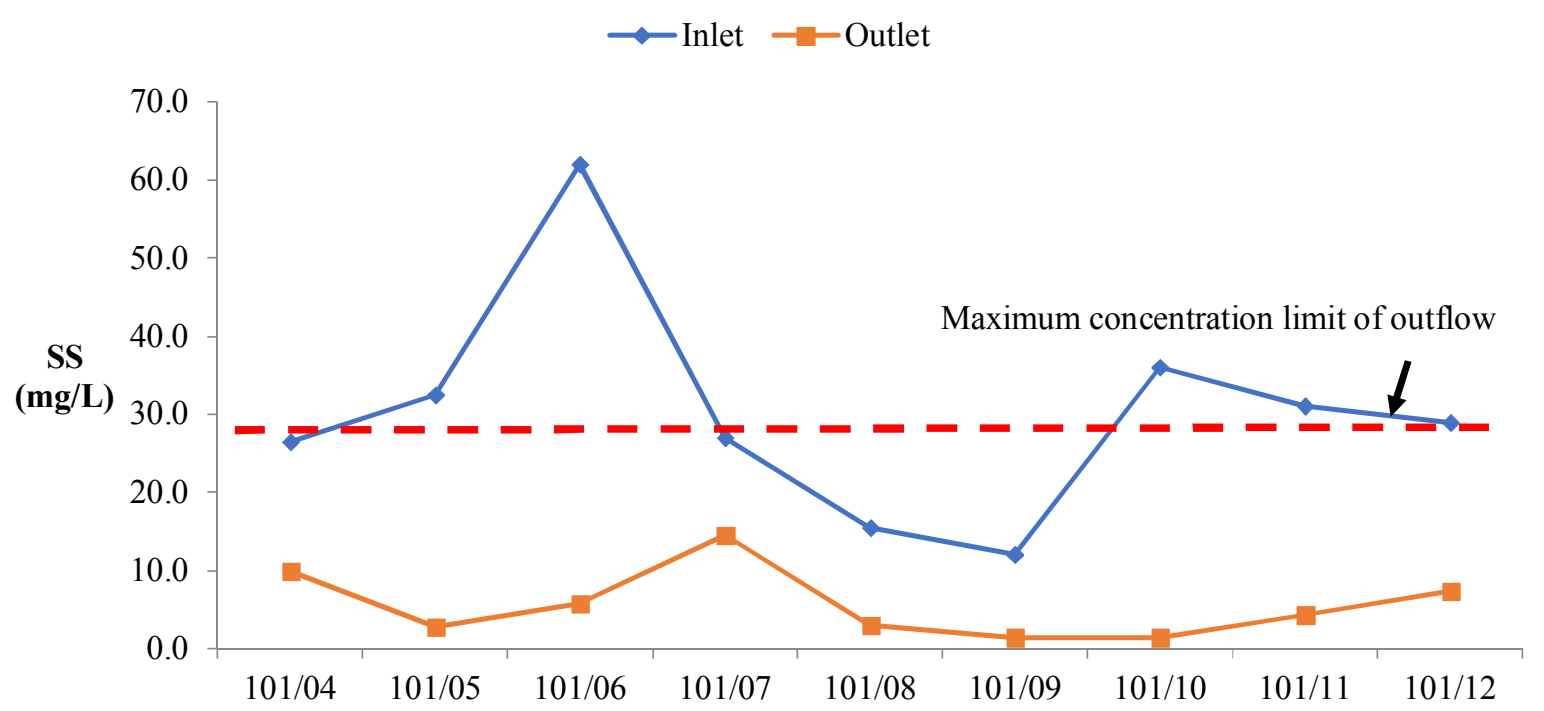

Figure 3. SS concentration variation of inflow and outflow in the entire system by gravel contact oxygen treatment and constructed wetland method.

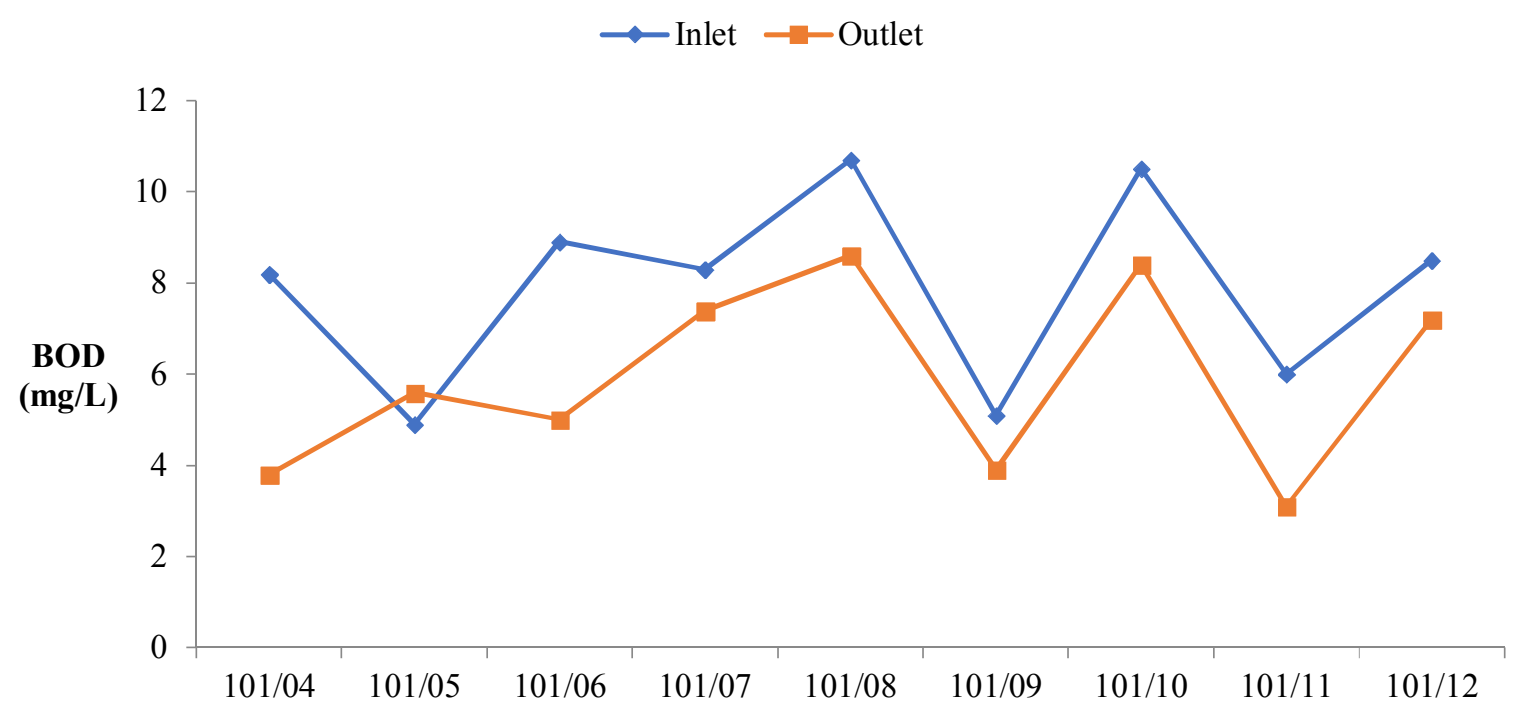

Figure 4. BOD concentration variation of inflow and outflow by using gravel contact oxygen treatment. 


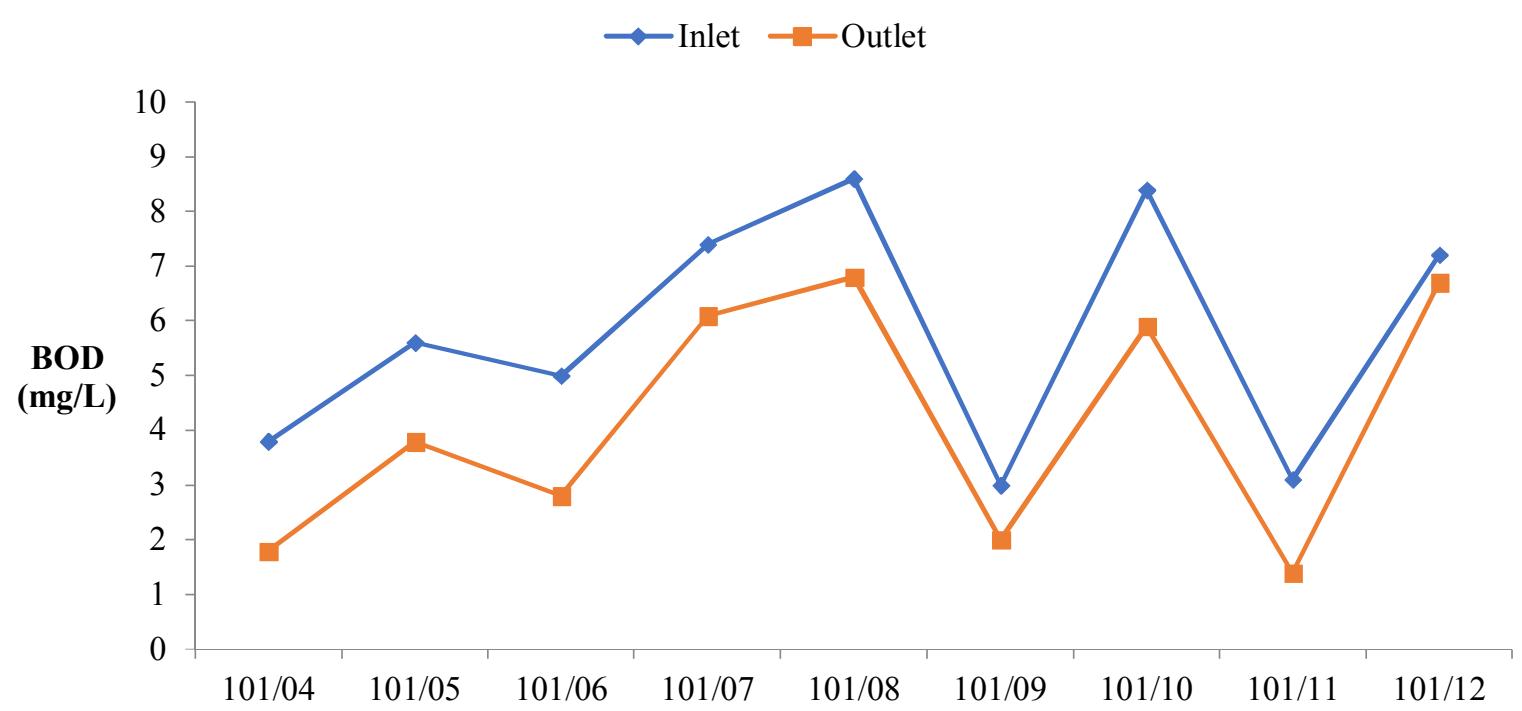

Figure 5. BOD concentration variation of inflow and outflow via constructed wetland method.

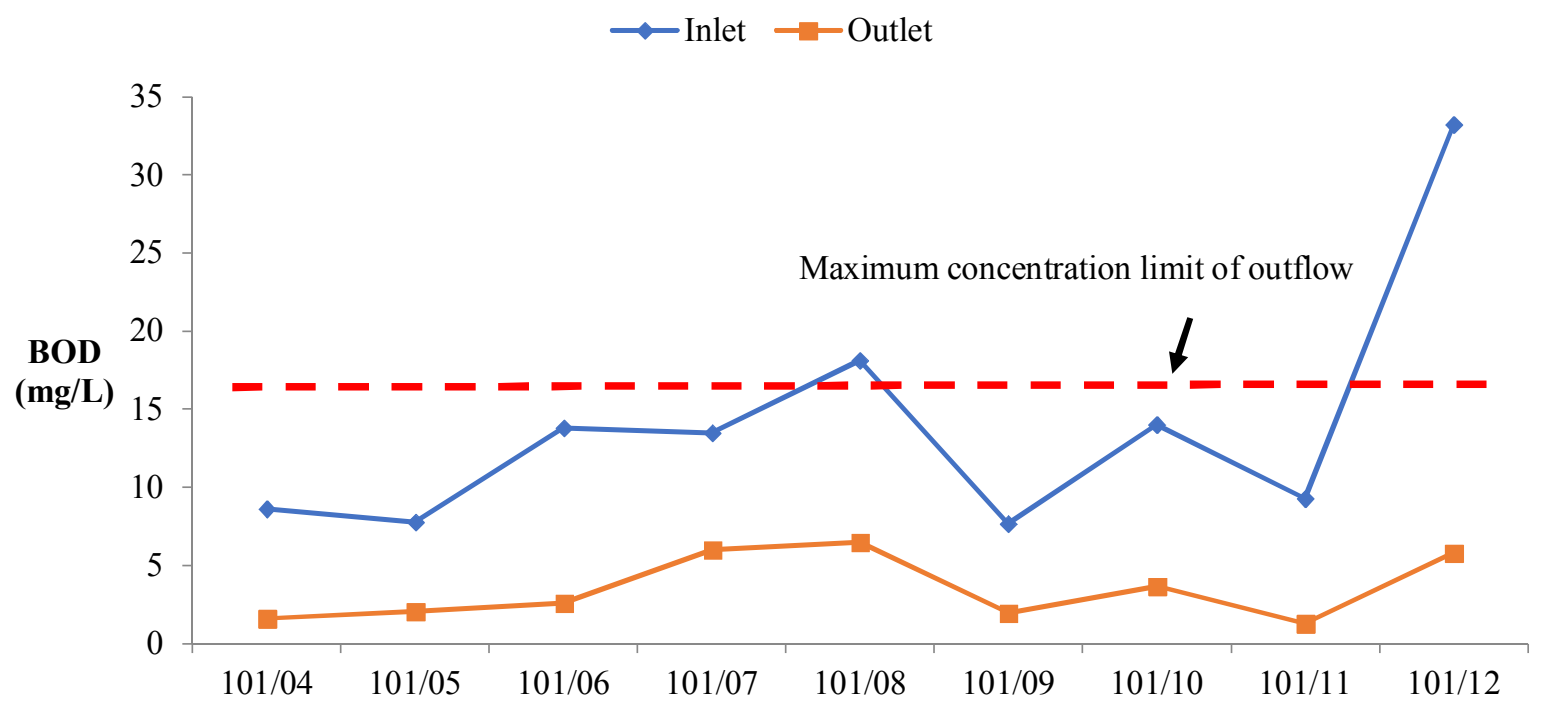

Figure 6. BOD concentration variation of inflow and outflow in the entire system by gravel contact oxygen treatment and constructed wetland method. 


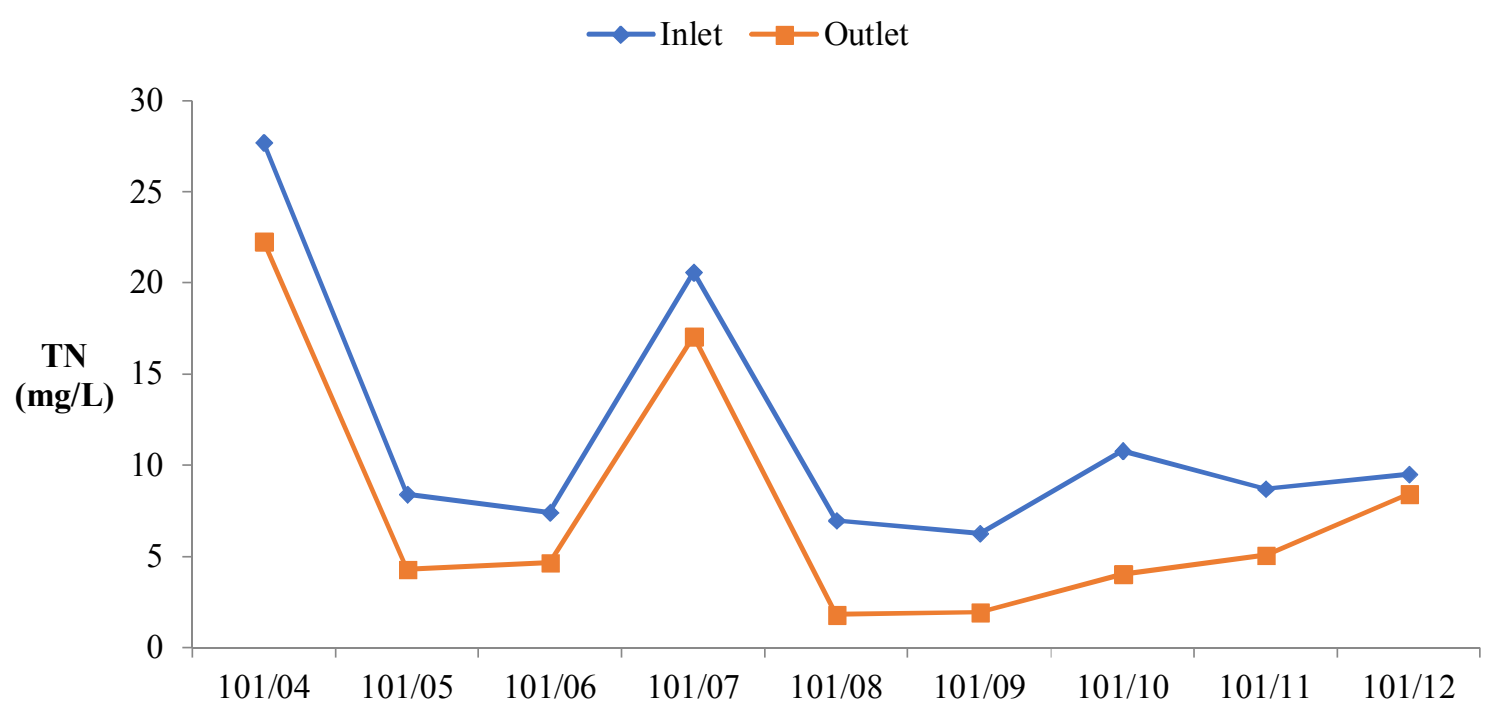

Figure 7. TN concentration variation of inflow and outflow by using gravel contact oxygen treatment.

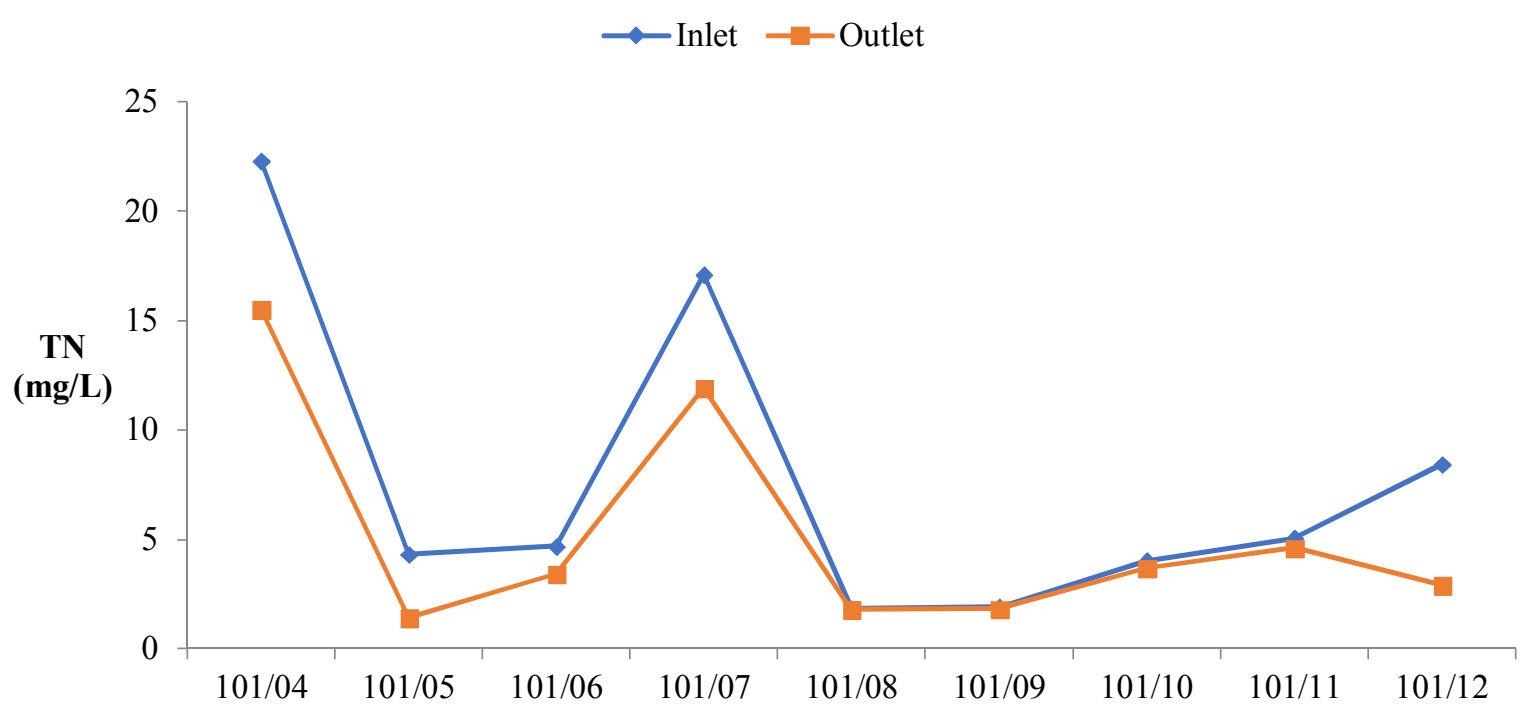

Figure 8. TN concentration variation of inflow and outflow via constructed wetland method. 


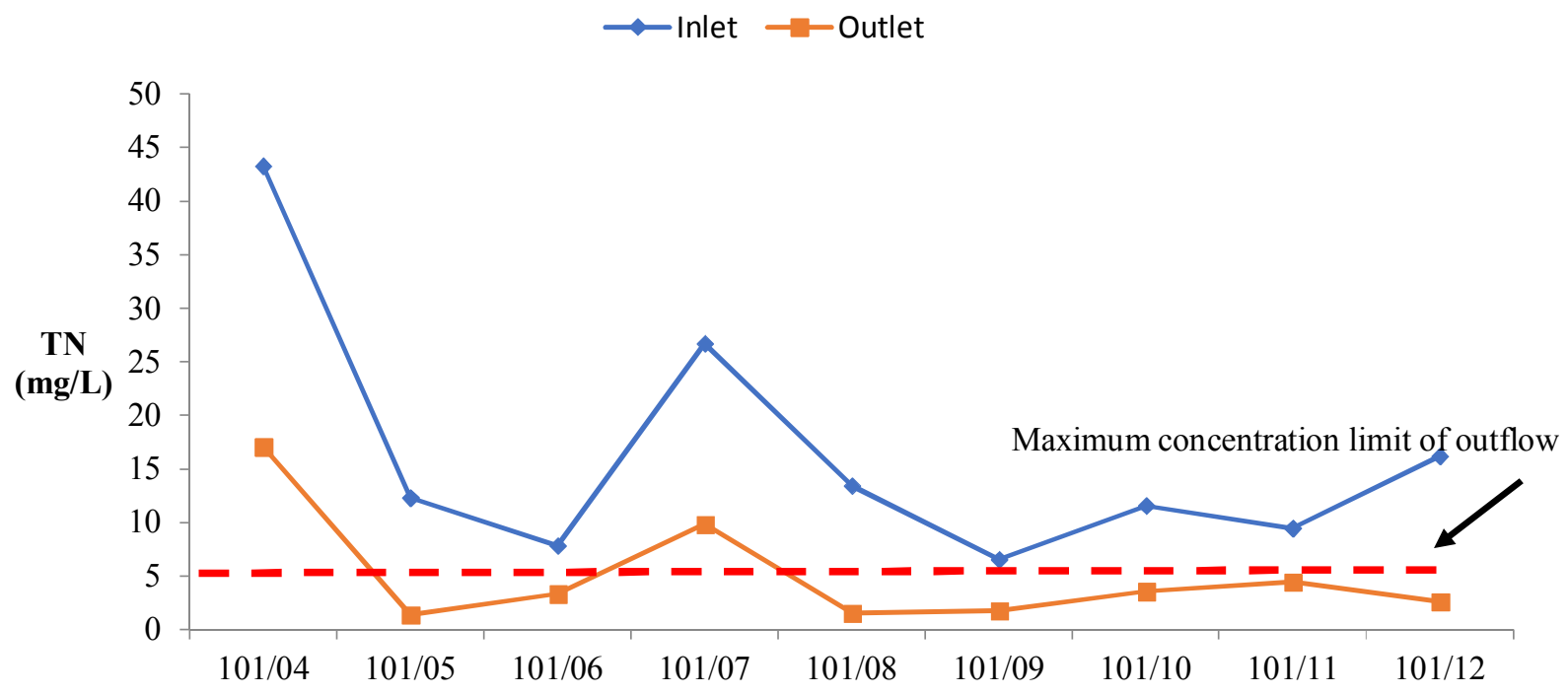

Figure 9. TN concentration variation of inflow and outflow in the entire system by gravel contact oxygen treatment and constructed wetland method.

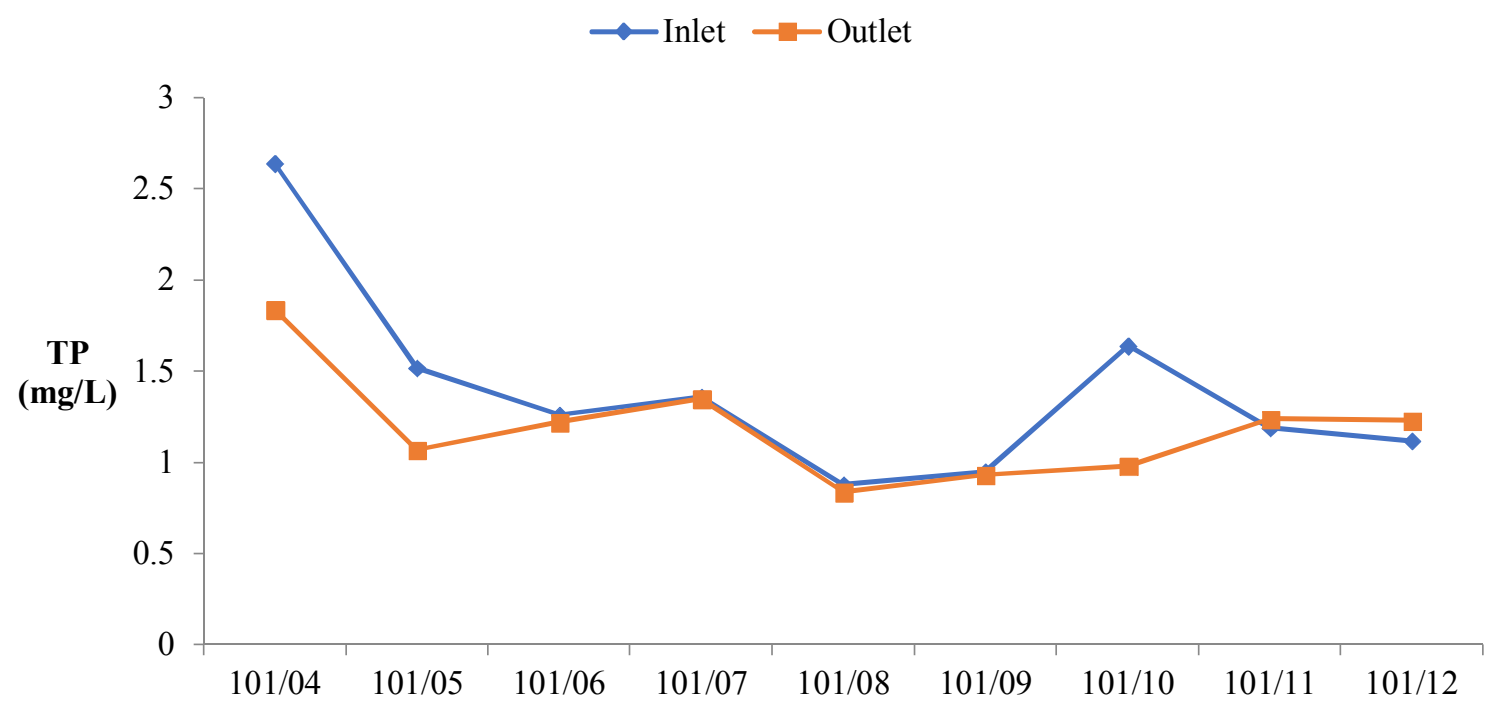

Figure $10 \mathrm{TP}$ concentration variation of inflow and outflow by using gravel contact oxygen treatment. 


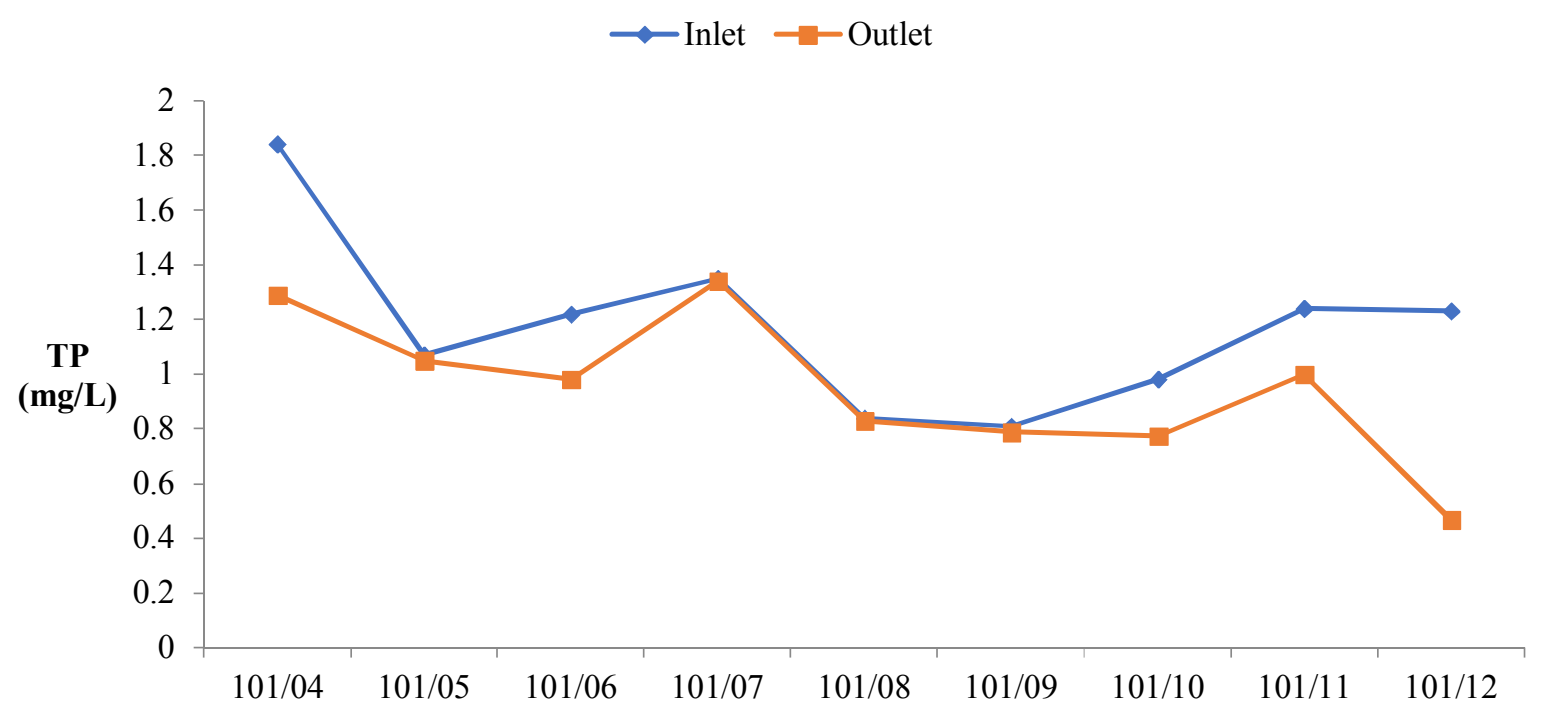

Figure 11. TP concentration variation of inflow and outflow via constructed wetland method.

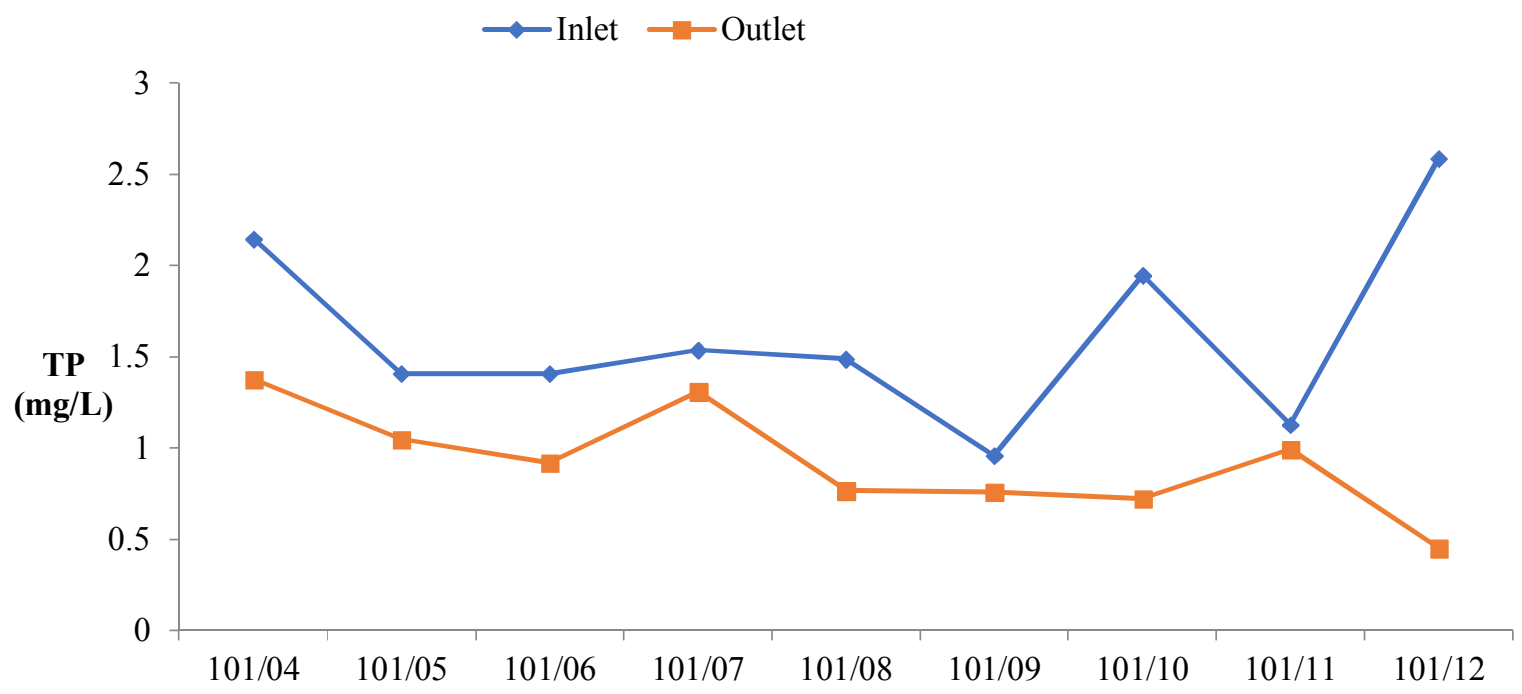

Figure 12. TP concentration variation of inflow and outflow in the entire system by gravel contact oxygen treatment and constructed wetland method. 


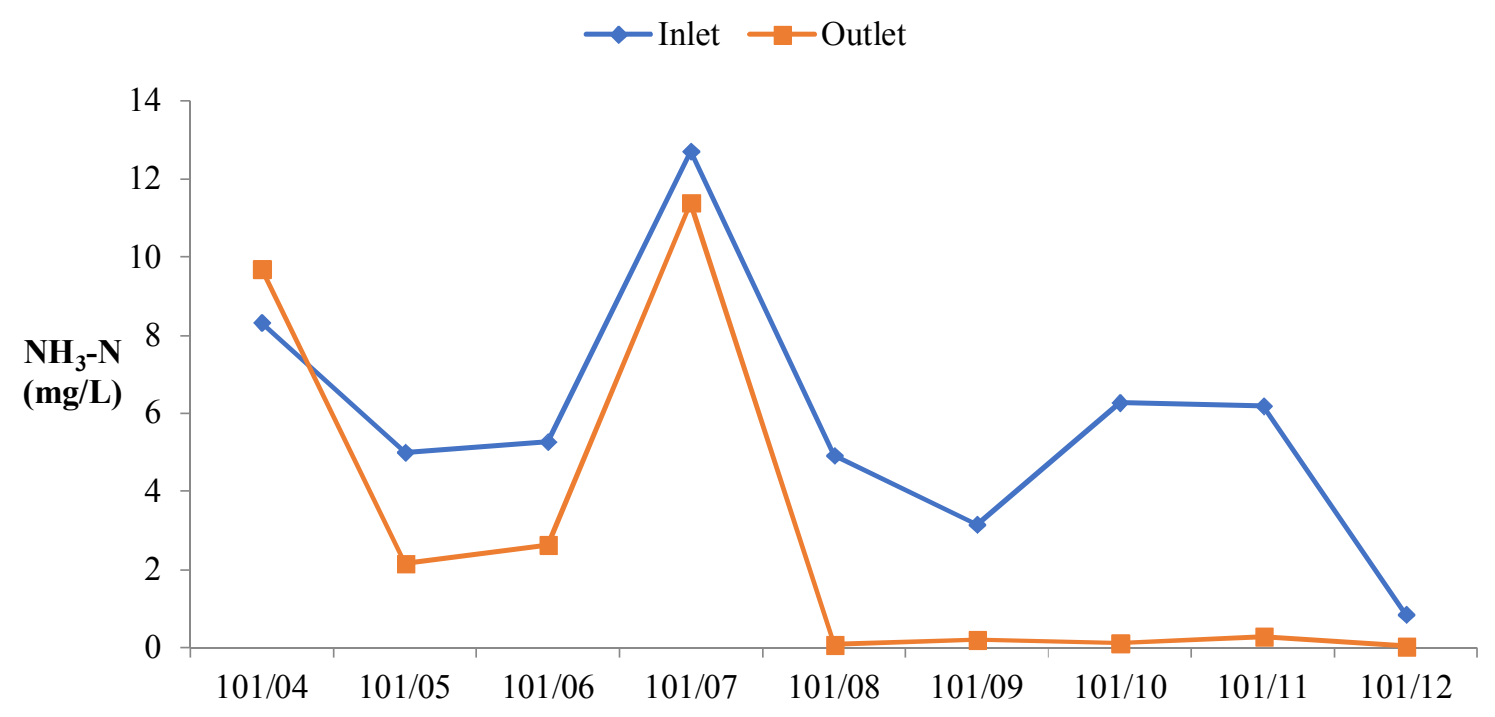

Figure 13. $\mathrm{NH}_{3}-\mathrm{N}$ concentration variation of inflow and outflow by using gravel contact oxygen treatment.

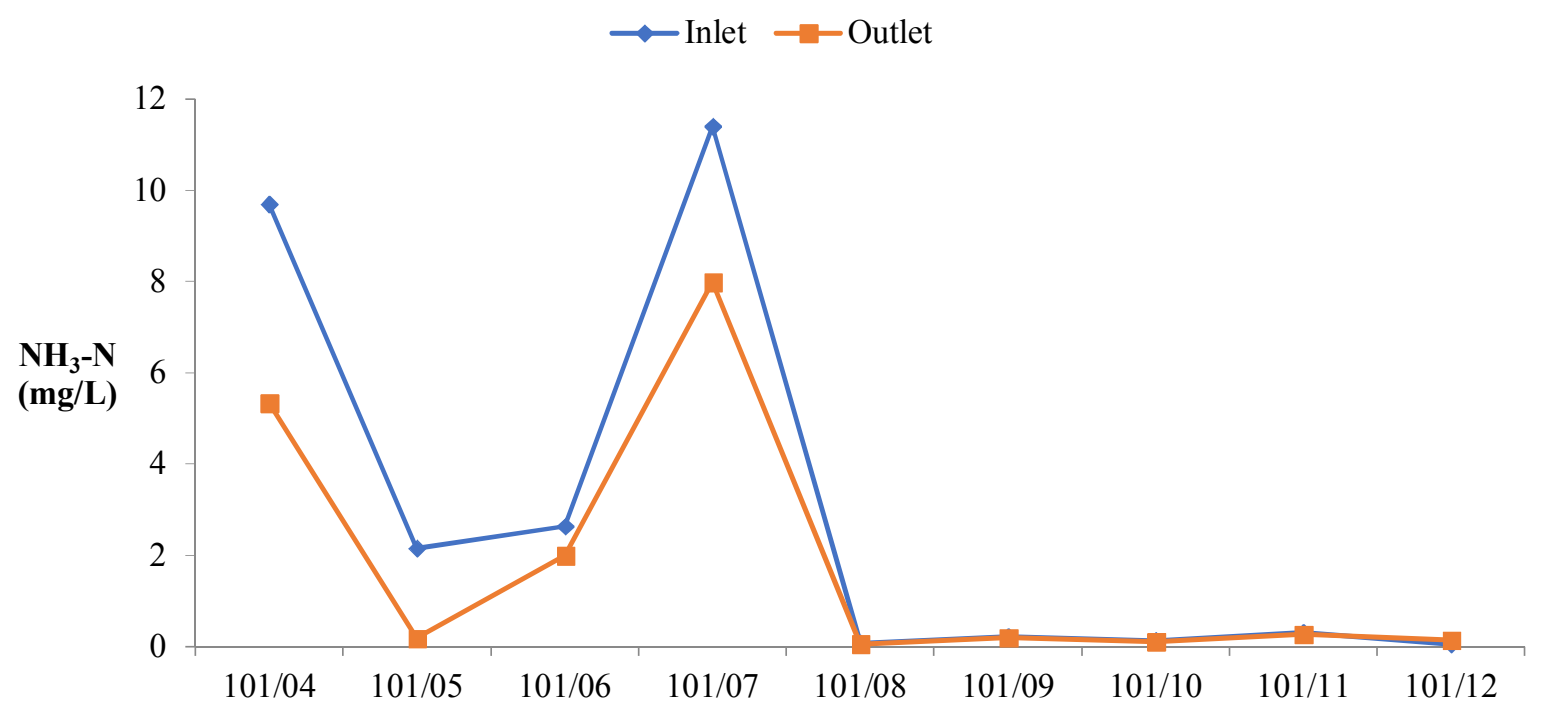

Figure 14. $\mathrm{NH}_{3}-\mathrm{N}$ concentration variation of inflow and outflow via constructed wetland method. 


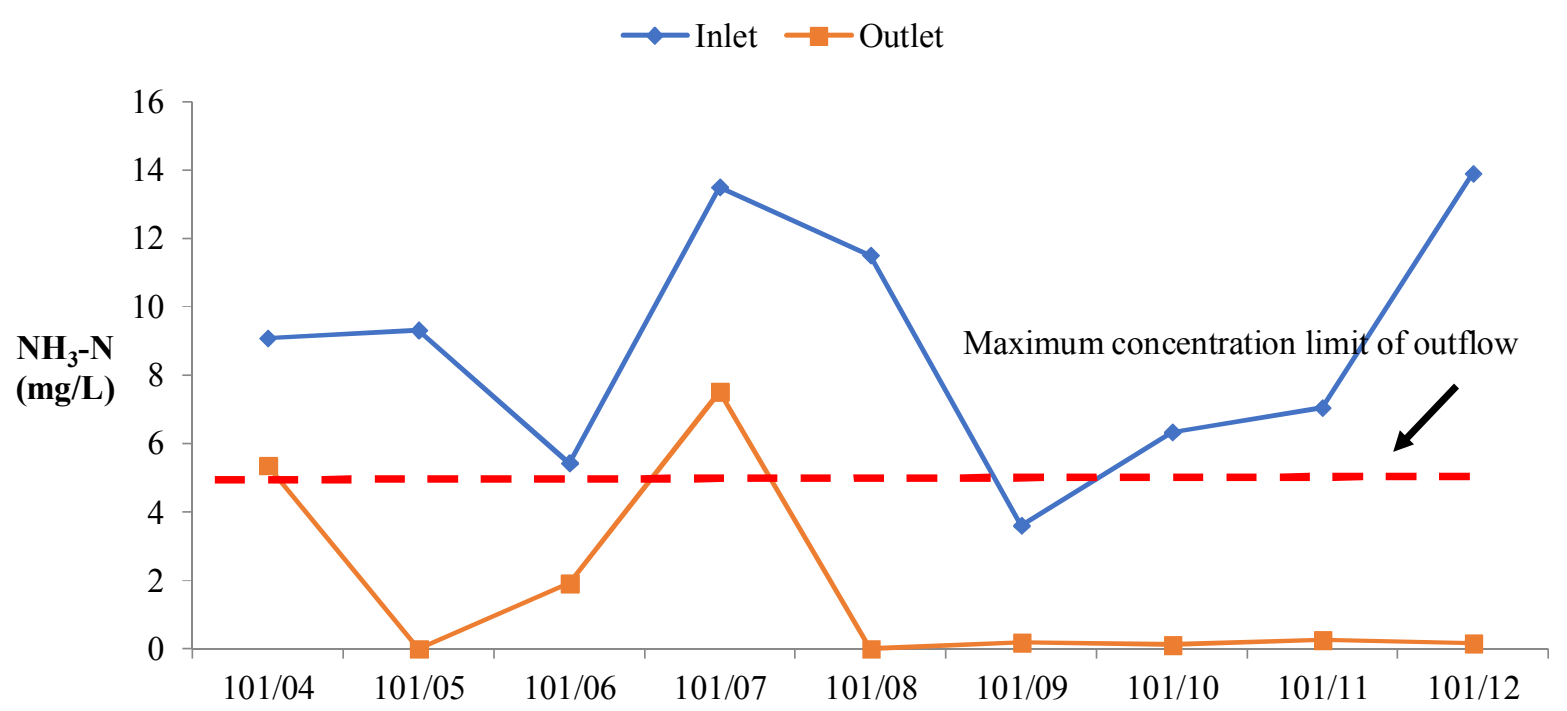

Figure 15. $\mathrm{NH}_{3}-\mathrm{N}$ concentration variation of inflow and outflow in the entire system by gravel contact oxygen treatment and constructed wetland method.

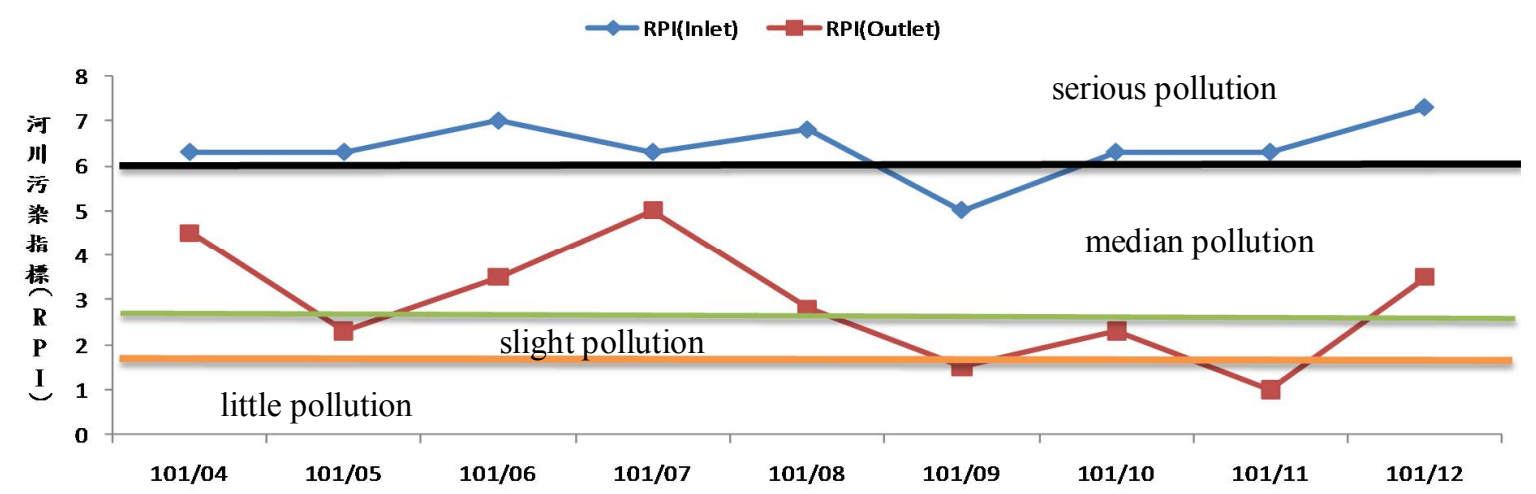

Figure 16. RPI values of inflow and outflow. 


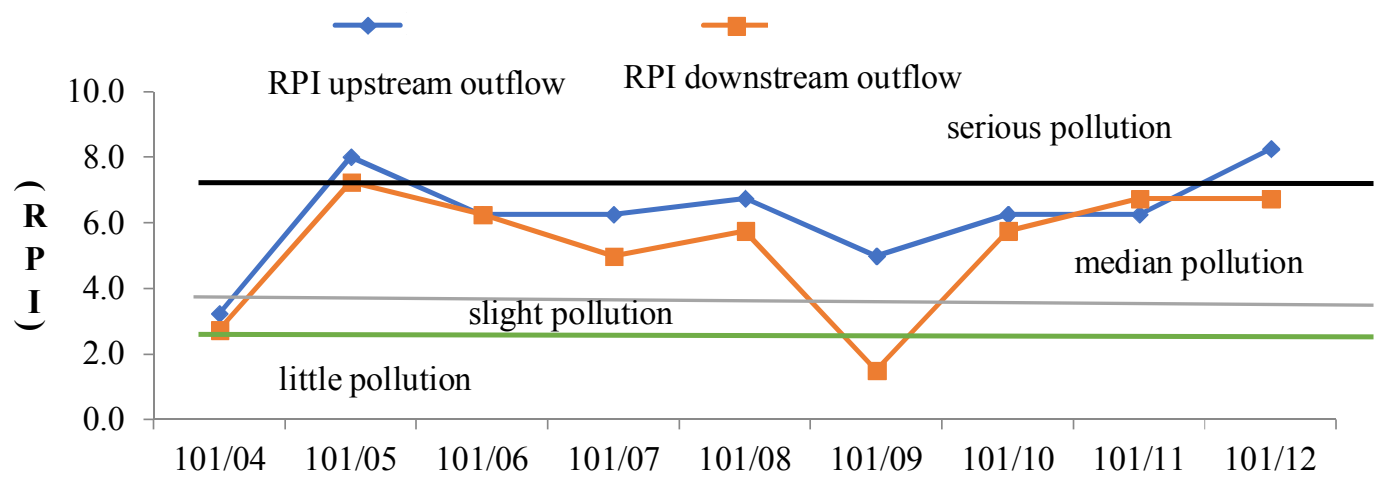

Figure 17. RPI values of upstream and downstream outflow. 